\title{
Impact of Curcumin-Mediated Photosensitization on Fungal Growth, Physicochemical Properties and Nutritional Composition in Australian Grown Strawberry
}

\author{
Shammy Sarwar ${ }^{1} \cdot$ Gabriele Netzel $^{1,2} \cdot$ Michael E. Netzel $^{1,2} \cdot$ Ram Mereddy $^{3} \cdot$ Anh Dao Thi Phan $^{1,2} \cdot$ Hung Trieu Hong ${ }^{1} \cdot$ \\ Daniel Cozzolino ${ }^{1,2} \cdot$ Yasmina Sultanbawa ${ }^{1,2}$ (D)
}

Received: 28 September 2020 / Accepted: 14 October 2020

(C) Springer Science+Business Media, LLC, part of Springer Nature 2020

\begin{abstract}
The effect of photosensitization mediated by curcumin on fungal growth, physicochemical properties and nutritional composition in Australian grown "Albion" strawberries was evaluated. Curcumin solution (1200, 1000 and $800 \mu \mathrm{M})$ was sprayed on the strawberry surface, followed by illumination using blue light $(420 \mathrm{~nm})$ for $10 \mathrm{~min}$ at a dosage of $42 \mathrm{~J} / \mathrm{cm}^{2}$ and stored at $4 \pm 2{ }^{\circ} \mathrm{C}$ for 12 days. The fruit photosensitized with $1000-\mu \mathrm{M}$ curcumin $\left(10 \mathrm{~min}\right.$, followed by storage at $\left.4 \pm 2{ }^{\circ} \mathrm{C}\right)$ lasted up to 12 days with a fungal infection rate of $52 \%$, whereas untreated control fruit developed $100 \%$ fungal infection and lasted for 8 days only under the same conditions. This treatment did not have an effect on colour, $\mathrm{pH}$, moisture content, titratable acidity, ascorbic acid, total phenolic content and anthocyanins, whereas total soluble solids $(9 \%)$ and total sugar $(22 \%)$ were increased $(p<0.05)$. These initial results indicate that curcumin-based photosensitization could be an effective non-thermal technology to preserve the nutritional quality as well as to extend the postharvest life of fresh strawberry fruit.
\end{abstract}

Keywords Photosensitization · Curcumin $\cdot$ Strawberry $\cdot$ Preservation $\cdot$ Shelf life $\cdot$ Nutritional quality

\section{Introduction}

Strawberry (Fragaria x ananassa Duch.) is a popular fruit and well known for its vibrant and colourful appearance as well as

\section{Highlights}

- Strawberry fruit treated with curcumin-based photosensitization.

- Extended storage life of treated strawberry in comparison to untreated control.

- Colour, phenolic content, anthocyanins and ascorbic acid remained unaffected.

- Total soluble solids and total sugar levels increased.

- Efficacy of photosensitization in strawberry demonstrated.

Yasmina Sultanbawa

y.sultanbawa@uq.edu.au

1 Centre for Nutrition and Food Sciences, Queensland Alliance for Agriculture and Food Innovation, The University of Queensland, St. Lucia, QLD 4072, Australia

2 ARC Training Centre for Uniquely Australian Foods, Centre for Nutrition and Food Sciences, Queensland Alliance for Agriculture and Food Innovation, The University of Queensland, Coopers Plains, QLD 4108, Australia

3 Department of Agriculture and Fisheries, Queensland Government, Coopers Plains, QLD 4108, Australia sweet taste. Strawberry, depending on cultivar, growing conditions, pre-and post-harvest treatment, can be a rich source of bioactive compounds such as anthocyanins, non-anthocyanin polyphenols and vitamin C (Nadim et al. 2015). However, high respiration rate, susceptibility to mechanical injury and contamination with fungi and bacteria can reduce their nutritional quality and shelf life considerably (Neri et al. 2015). Edible coating (Yan et al. 2019), gamma-radiation (Maraei and Elsawy 2017), ultrasound (Cheng et al. 2014), ozone, gaseous chlorine dioxide (Chiabrando et al. 2018) and modified atmosphere packaging (Matar et al. 2018) have been investigated for preserving strawberries. The use of various fungicides is possibly the most commonly used method to control postharvest decay, but these are environmentally unfriendly and some even hazardous to human health (Liu et al. 2018). Therefore, there is a need to develop environmentally friendly and sustainable technologies, to extend postharvest storage life and to retain the nutritional quality of strawberry fruit.

Photosensitization is a novel environmentally friendly treatment to inactivate microorganisms via cytotoxic reactive oxygen species (ROS) produced by the photoactive compound (photosensitizer) after visible light illumination (Jiang et al. 2013). In the last few decades, photosensitization has been used for treating cancer, skin diseases and endodontic 
infections, but also in different food related applications (Strazzi Sahyon et al. 2019). Compared to other antimicrobial "tools", one of the most important advantages of photosensitization is the absence of any microbial resistance (Brovko et al. 2014).

Curcumin (CUR), a natural photosensitizer, has in vitro anti-inflammatory, antimicrobial and antioxidant properties (Penha et al. 2017). This bioactive compound has been used as a food-grade photosensitizer to reduce microbial growth and to increase the shelf life of freshcut Hami melons (Lin et al. 2019), apples (Tao et al. 2019), date fruit (Al-Asmari et al. 2018), maize kernels (Temba et al. 2019) and oysters (Liu et al. 2016). Previous studies have shown that photosensitization was successfully applied to decontaminate fungal spores (AlAsmari et al. 2017), Gram-positive and Gram-negative bacteria such as Staphylococcus aureus, Escherichia coli, Salmonella typhimurium (Penha et al. 2017) and Vibrio parahaemolyticus (Chen et al. 2020) as well as microfungi and yeasts (Rasiukevičiūtè et al. 2015). Compared to conventional preservation technologies, photosensitization possesses a stronger antimicrobial effect and is less expensive. Furthermore, this novel technology may also preserve the colour, aroma and freshness of the treated foods (Lin et al. 2019).

The aims of the present study were to evaluate the effect of photosensitization on visual fungal growth as well as selected physicochemical parameters and nutritional composition in Australian grown strawberries. The results of this study could provide an avenue to assess the suitability of photosensitization as a sustainable and safe preservation technology for fresh horticultural products.

\section{Material and Methods}

\section{Materials}

Fresh strawberries (13 kg) of "Albion" variety were collected from a local supermarket in Brisbane (QLD, Australia). Fruits of uniform size (diameter $30 \pm 2 \mathrm{~mm}$ ) and colour were selected and stored at $4 \pm 2{ }^{\circ} \mathrm{C}$ prior to photosensitization carried out within $6 \mathrm{~h}$ of collection.

\section{Preparation of Photosensitizer Solution}

A stock solution of 2000- $\mu \mathrm{M}$ CUR was freshly prepared in propylene glycol and water (30:70). The stock solution was kept at $4{ }^{\circ} \mathrm{C}$ in a dark place and used within $6 \mathrm{~h}$. Serial dilutions of 1200,1000 and $800 \mu \mathrm{M}(\mathrm{pH}$ 5.3) were prepared from the stock solution.

\section{Light Source and Sample Treatment}

A xenon arc lamp (Polilight 500®, Rofin Australia Pty Ltd., Dingley, VIC, Australia) emitting visible light in the region of 400 to $700 \mathrm{~nm}$, equipped with an optical fibre light guide was used as a light source for photosensitization. The maximum absorbance wavelength $\left(\lambda_{\max }\right)$ of CUR $(420 \mathrm{~nm})$ was determined from the absorption spectrum measured using a spectrophotometer (Infinite M200, Tecan, Grödig, Austria). The light dosage on the surface of the samples was $42 \mathrm{~J} / \mathrm{cm}^{2}$.

Strawberry (fresh) fruit was sprayed with approximately $1 \mathrm{~mL}$ of $1000 \mu \mathrm{M}$ CUR solution, followed by air-drying for about $15 \mathrm{~min}$ at room temperature in the dark (Fig. 1). Each fruit was placed in an "in-house built" continuous rotator moving at a very slow speed $(2 \mathrm{rpm})$ for $10 \mathrm{~min}$ at a $10-\mathrm{cm}$ distance from the light source. It was ensured that the whole surface of the fruit was illuminated uniformly during this period.

\section{Visual Inspection of Fruit}

For visual inspection of fungal growth, fruits were divided into 6 groups. The treated five groups were $\mathrm{L}-\mathrm{C}+$, no light but only CUR; L+ C-, only light but no CUR; L+ C+(1200), light and CUR $(1200 \mu \mathrm{M}) ; \mathrm{L}+\mathrm{C}+(1000)$, light and CUR $(1000 \mu \mathrm{M}) ; \mathrm{L}+\mathrm{C}+(800)$, light and CUR $(800 \mu \mathrm{M})$ and control (untreated). Three replicates each containing eighteen fruits were prepared for each individual group $(n=54)$. The strawberries were examined for fungal growth and surface colour changes during $0,4,8$ and 12 days of storage at $4 \pm 2{ }^{\circ} \mathrm{C}$. As fungal growth on fruit surface is a vital index for quality and shelf life, any growth (slight, moderate or severe) that emerged on the fruit surface was considered fungal infection (rotten) and treated as the end of shelf life (Al-Asmari et al. 2018). The results were expressed as percentage of infected fruit.

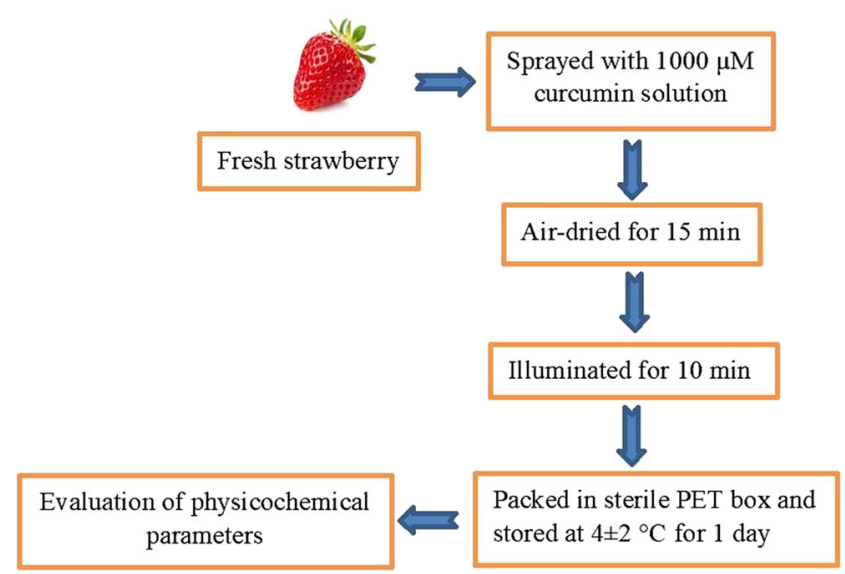

Fig. 1 Schematic diagram of photosensitization 


\section{Determination of Physicochemical Parameters}

For the determination of physicochemical parameters, the first group $(n=54)$ were photosensitized with light $(420 \mathrm{~nm})$ and $1000-\mu \mathrm{M}$ CUR. The second group (54 fruits) were untreated strawberry, labelled as the control and stored at room temperature in the dark. After photosensitization, fruits were packed into sterile clear polyethylene terephthalate (PET) punnet box and all samples (including control) stored at $4 \pm 2{ }^{\circ} \mathrm{C}$ for 1 day.

After 1 day, both control and photosensitized samples were evaluated for tristimulus colour, moisture content, titratable acidity, total soluble solids and $\mathrm{pH}$. The rest of the strawberry fruits (whole or cut) were freeze-dried and stored in airtight container at $-20{ }^{\circ} \mathrm{C}$ until further analysis. Six fruit samples were evaluated for tristimulus colour using a Minolta colourimeter (Minolta Co. Ltd., Osaka, Japan). $L^{*}, C^{*}$ and $h^{\circ}$ values were recorded. $L^{*}$ is the lightness and corresponds to a black-white scale, $h^{\circ}$ is the hue angle on the colour wheel and $C^{*}$ is the chroma, a measure of the intensity of colour. Colour was determined in triplicate.

After colour determination, each strawberry was longitudinally cut into four identical segments. All sub-samples were individually blended into puree using a hand blender (Braun 600 watt, Braun, London, UK) and divided into 2 sub-samples. One sub-sample of strawberry puree was used for determining titratable acidity (TA), $\mathrm{pH}$ using an automated titration system (Metrohm 795 Karl Fischer Titrator System, Metrohm, Herisau, Switzerland) and moisture content. TA was expressed as g citric acid equivalents (CAE)/100 g fresh weight (fw). Another sub-sample was used for measuring total soluble solids (TSS) content using a Pal-1 hand refractometer (ATAGO, Co. Ltd., Osaka, Japan) and the maturity index was calculated as the ratio between TSS and TA.

\section{DPPH Radical Scavenging Capacity}

The DPPH (1,1-diphenyl-2-picrylhydrazyl) assay was performed in a 96-well microtiter plate as described by Musa et al. (2013). Trolox (6-hydroxy-2, 5, 7, 8 tetramethylchroman-2carboxylic acid) was used as standard and concentrations between 5 and $50 \mu \mathrm{M}$ were used for calibration. Results were expressed as $\mu \mathrm{M}$ Trolox equivalents (TE)/100 $\mathrm{g}$ fw.

\section{Total Phenolic Content (TPC)}

TPC was determined using a micro-plate absorbance reader (Infinite M200, Tecan, Mannedorf, Switzerland) following the method of Netzel et al. (2012). Gallic acid was used as standard and results were expressed as mg gallic acid equivalents (GAE)/100 g fw.

\section{Analysis of Anthocyanins}

Anthocyanins were analyzed using an Agilent 1290 Infinity UHPLC-PDA System (Agilent Technologies, Santa Clara, CA, USA), following the methods of Gasperotti et al. (2015). Pelargonidin 3-glucoside, cyanidin 3-glucoside and pelargonidin 3-rutinoside were identified by LCMS (data not shown) and quantified using an external calibration of pelargonidin-3-glucoside. Results were expressed as mg/ $100 \mathrm{~g} \mathrm{fw}$.

\section{Analysis of Ascorbic Acid}

Ascorbic acid was analyzed as previously reported by Phan et al. (2019). Results were expressed as $\mathrm{mg} / 100 \mathrm{~g}$ fw.

\section{Analysis of Sugars}

Sugar was analyzed as previously reported by Phan et al. (2019). Glucose, fructose and sucrose were quantified using external calibrations. The results were expressed as total sugar $\mathrm{g} / 100 \mathrm{~g}$ fw (sum of glucose, fructose and sucrose).

\section{Statistical Analysis}

Results are presented as the mean \pm standard deviation (SD) of three replicates. Statistical significance was determined using Student's $t$ test when comparing two groups or using one or two-way ANOVA followed by Tukey's multiple comparisons when comparing three or more groups. The difference between the means was considered statistically significant when $p<0.05$. All statistical calculations were performed using GraphPad Prism 8.0.1 (GraphPad software, San Diego, CA, USA).

\section{Results and Discussion}

\section{Effect of Photosensitization on Visual Observation of Fungal Growth}

In the present study, among the three different CUR concentrations used, $1000 \mu \mathrm{M}$ was found to be more effective ( $p<$ 0.05 ) in reducing fungal growth during storage than the other two treatments (Fig. 2). After 12 days of storage, $52 \%$ of the photosensitized strawberry samples (using CUR $1000 \mu \mathrm{M}$ ) were infected in comparison to $100 \%$ in the untreated control after only 8 days of storage. On the other hand, samples photosensitized with 1200 and $800 \mu \mathrm{M}$, the fungal infection was $86 \%$ and $79 \%$, respectively, after 12 days of storage. Strawberry samples, treated with only light (no CUR) and only CUR (no light), showed a fungal infection rate of $100 \%$ after 12 days and 8 days, respectively. These results 
Fig. 2 Effect of

photosensitization (light dosage $42 \mathrm{~J} / \mathrm{cm} 2$ ) mediated by CUR at various concentrations and light or CUR treatment alone on fungal growth on strawberry surface stored at $4 \pm 2{ }^{\circ} \mathrm{C} \mathrm{L}-\mathrm{C}+=$ no light only CUR; $\mathrm{L}+\mathrm{C}-=$ only light no CUR; L+ C+(1200) = both light and CUR $(1200 \mu \mathrm{M})$, $\mathrm{L}+\mathrm{C}+(1000)=$ both light and $\operatorname{CUR}(1000 \mu \mathrm{M}), \mathrm{L}+\mathrm{C}+(800)=$ both light and CUR $(800 \mu \mathrm{M})$; control $=$ untreated. $* p<0.05$ compared to the control group without CUR and light treatment. Data represent mean $\pm \mathrm{SD}(n=3)$

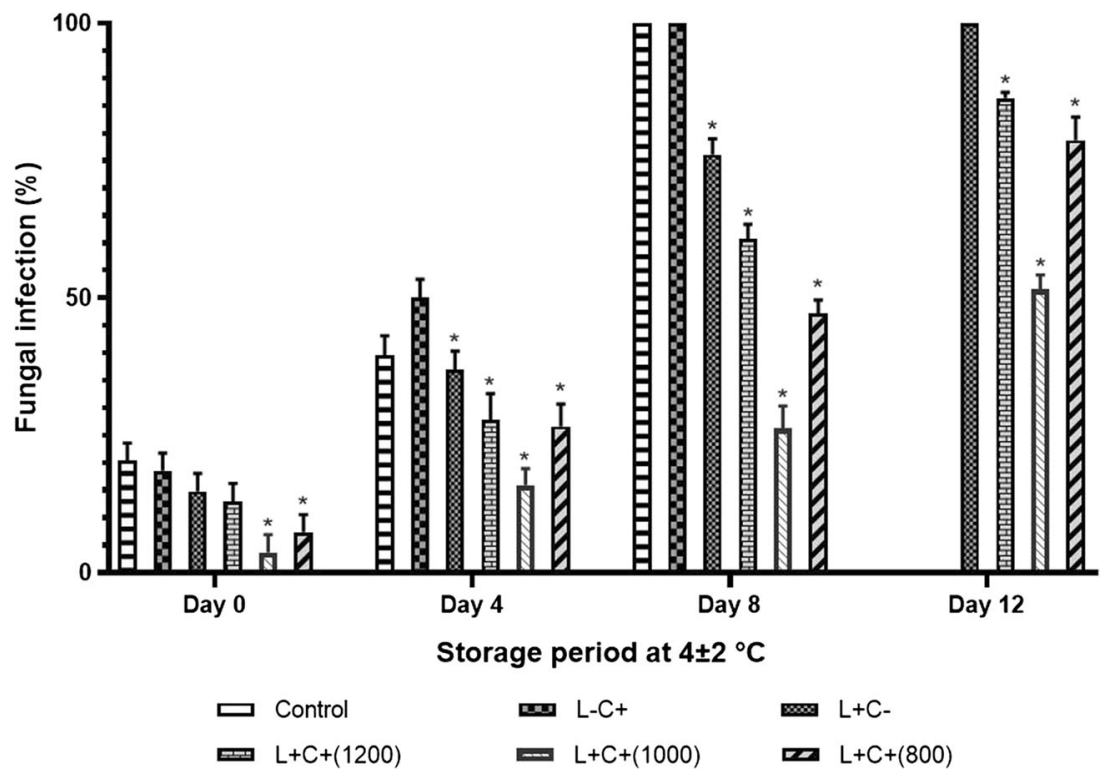

indicate that neither light alone nor CUR alone has any effect on strawberry shelf life. Based on these findings, the physicochemical and nutritional analysis were performed on the samples photosensitized with $1000-\mu \mathrm{M}$ CUR and 10-min exposure to blue xenon light $(420 \mathrm{~nm})$.

The most important requirement of any preservation technology is the ability to extend the shelf life of food. In this study, the combination of 1000- $\mu$ M CUR and light resulted in a significant $(p<0.05)$ extension of the shelf life and quality retention of "Albion" strawberries (Fig. 2). We have hypothesized that the extension of shelf life might have been achieved via the following mechanism. Free CUR molecules in the mixture get excited and produce ROS, and these reactive chemical species target the fungal/spores/cells causing perforation of the cell membranes, which in turn increased the permeability and allowed the photosensitizer to penetrate into the cell, causing cell component oxidation after illumination and leading to cell death (Priyadarsini 2014). The alterations caused in the fungal cell membrane by ROS can be cross-linking, lipid peroxidation, enzyme and protein inactivation and membrane leakage, leading to lysis of cell membranes (Al-Asmari et al. 2017).

Similar results were reported by Al-Asmari et al. (2018) where date fruit photosensitized using $1400 \mu \mathrm{M}$ CUR for $10 \mathrm{~min}$, stored at $30^{\circ} \mathrm{C}$ lasted for 14 days in comparison to the 7 days for the control. Paskeviciute et al. (2018) reported that chlorophyllin-based photosensitization at a light dose of $3 \mathrm{~J} / \mathrm{cm}^{2}$ prolonged the shelf life of cherry tomatoes by 4 days. In another report by Liu et al. (2016), an extension of shelf life of oyster of up to 12 days after treatment using $10-\mu \mathrm{M}$ CUR at a light dose of $5.4 \mathrm{~J} / \mathrm{cm}^{2}$ could be observed.

Reduction of fungal growth was reported with CUR concentrations from 600 to $1000 \mu \mathrm{M}$. The fungal species, including A. niger, A. flavus, P. griseofulvum, P. chrysogenum and
Z. bailii, were significantly reduced by $1.98 \log , 0.95 \log , 0.66$ $\log , 2.49 \log$ and $2.09 \log \mathrm{CFU} / \mathrm{g}$, respectively, when photosensitized with a light dose of $96 \mathrm{~J} / \mathrm{cm}^{2}$ (Al-Asmari et al. 2017). Luksiene and Paskeviciute (2011) found that photosensitization-based treatment can decontaminate strawberry from the surface inoculated Listeria by $98 \%$, mesophylls naturally distributed on the surface of strawberries by $97 \%$, yeasts and fungi by $86 \%$. Meanwhile, in our study, the overall reduction of microbial contamination resulted in extending the storage life of treated strawberries by 4 days in comparison to the control (Fig. 2). Hence, photosensitization can be considered a clean green technology in preserving strawberry fruit.

\section{Measurements of Colour}

Colour is one of the most important factors that can affect consumer perception of strawberries (Nunes et al. 1995). No colour changes $(p>0.05)$ were detected in treated strawberries in comparison with the control (Table 1) after $24 \mathrm{~h}$ of storage at $4{ }^{\circ} \mathrm{C}$. This is supported by a previous study that showed photosensitization mediated by chlorophyllin had no impact on strawberry colour (Rasiukevičiūtè et al. 2016).

\section{TSS, TA, pH and Moisture Content}

TSS increased significantly $(p<0.05)$ in the treated samples compared to the control after 1 day of storage. Both $\mathrm{pH}$ and TA of photosensitized fruits did not change $(p>0.05)$ when compared to the control fruit. In our study, TSS and maturity index (TSS/TA ratio) increased $(p<0.05)$ in the treated samples compared to the untreated control (Table 1). In this study, the moisture contents were $88.8 \%$ and $88.5 \%$ in the control and treated samples, respectively. 
Table 1 Effect of photosensitization on physicochemical properties of Albion strawberries

\begin{tabular}{|c|c|c|c|c|c|c|c|c|}
\hline & \multicolumn{3}{|l|}{ Colour } & \multirow[t]{2}{*}{ TSS $\left({ }^{0}\right.$ Brix $)$} & \multirow[t]{2}{*}{ TA (g CAE/100 g fw) } & \multirow[t]{2}{*}{$\mathrm{TSS} / \mathrm{TA}$ ratio } & \multirow[t]{2}{*}{$\mathrm{pH}$} & \multirow[t]{2}{*}{ Moisture (\%) } \\
\hline & $L^{*}$ & $C^{*}$ & $\mathrm{~h}^{\circ}$ & & & & & \\
\hline Control & $35.72 \pm 0.61$ & $40.22 \pm 0.44$ & $34.53 \pm 0.25$ & $7.20 \pm 0.09$ & $0.84 \pm 0.00$ & $8.54 \pm 0.09$ & $3.56 \pm 0.02$ & $88.79 \pm 0.17$ \\
\hline Treated & $35.61 \pm 0.42$ & $40.36 \pm 0.66$ & $34.57 \pm 0.15$ & $7.82 \pm 0.24^{\mathrm{a}}$ & $0.83 \pm 0.01$ & $9.36 \pm 0.29^{\mathrm{a}}$ & $3.55 \pm 0.01$ & $88.51 \pm 0.73$ \\
\hline
\end{tabular}

Data are mean $\pm \operatorname{SD}(n=3)$. Treated samples: $1000-\mu \mathrm{M}$ CUR and 10 min exposure to light (light dosage $\left.42 \mathrm{~J} / \mathrm{cm}^{2}\right) .{ }^{a} p<0.05$ compared to the control group. $L^{*}$, lightness; $C^{*}$, chroma; h , hue angle

\section{TPC and DPPH Radical Scavenging Capacity}

This study showed that photosensitization mediated by CUR "preserved" TPC (241.79 vs. $246.47 \mathrm{mg} \mathrm{GAE} / 100 \mathrm{~g} \mathrm{fw}$ ) after 1 day of storage (Table 2). In contrast, Luksiene and Paskeviciute (2011) found that TPC in strawberries treated with chlorophyllin-based photosensitization stored at $6{ }^{\circ} \mathrm{C}$ decreased (20\%) during $24 \mathrm{~h}$. However, Tao et al. (2019) reported that CUR- based photosensitization increased TPC in treated fresh-cut apple slices up to day 4 of storage at $4{ }^{\circ} \mathrm{C}$, which could be caused by oxidative stress (Sikora and Swieca 2018).

According to the results shown in Table 2, photosensitization mediated by CUR had no adverse effect on the DPPH radical scavenging capacity in the treated samples. On the other hand, Xu et al. (2014) found that blue light (470 nm) increased DPPH radical scavenging capacity in strawberries after 4 days of storage, which could be associated with enhanced cellular capacity to detoxify ROS and increased total phenolic content. In this study, photosensitization did not affect TPC and DPPH radical scavenging capacity of the treated samples could be due to the superficial action of the treatment (Paskeviciute et al. 2018).

\section{Anthocyanins Content}

In this study, the total anthocyanin content in control strawberry was $22.49 \mathrm{mg} / 100 \mathrm{~g}$ fw, which is within the range of 15$84 \mathrm{mg} / 100 \mathrm{~g}$ fw reported in previous studies for commercial strawberry cultivars (Fredericks et al. 2013). Total anthocyanin content after photosensitization remained similar to the control (Fig. 3). Pelargonidin-3-glucoside (Pg3G), cyanidin-3-glucoside (Cy3G) and pelargonidin-3-rutinoside (Pg3R) were unaffected by photosensitization. In contrast, Luksiene and Paskeviciute (2011) found that anthocyanins in strawberry samples treated with chlorophyllin-based photosensitization stored at $6{ }^{\circ} \mathrm{C}$ decreased (14\%) during $24 \mathrm{~h}$.

The anthocyanin content is responsible for the red colour of ripe strawberries. Several reports have indicated that ultraviolet (UV) light exposure promotes anthocyanin synthesis in strawberries and sweet cherries (Wang et al. 2009). Some previous reports showed that blue light increased the production of polyphenols, mainly flavonoids, which are UVabsorbing compounds with antioxidant capacity, and act as UV filters (Agati and Tattini 2010). One of the key enzymes in the synthesis of phenolic compounds is phenylalanine ammonia-lyase (PAL) and its activity is correlated with the content of phenolic compounds (Lemoine et al. 2010). Preservation of phenolic compounds and particularly anthocyanins in the present study could be the consequence of a combined effect of CUR and visible light induction of PAL (Xu et al. 2014). This indicates that photosensitization not only extends shelf life but also preserves bioactive compounds such as anthocyanins in strawberry fruit.

\section{Ascorbic Acid Content}

In this study, ascorbic acid in control strawberry was $46.98 \mathrm{mg} /$ $100 \mathrm{~g}$ fw which is within the reported range of $32-112 \mathrm{mg} /$

Table 2 Effect of photosensitization on quality parameters of Albion strawberries

\begin{tabular}{llllll}
\hline & TPC (mg GAE/100 g fw) & $\begin{array}{l}\text { DPPH radical scavenging } \\
\text { capacity }(\mu \mathrm{M} \text { TE/100 } \mathrm{g} \mathrm{fw})\end{array}$ & $\begin{array}{l}\text { Total anthocyanins } \\
(\mathrm{mg} / 100 \mathrm{~g} \text { fw })\end{array}$ & Ascorbic acid (mg/100 g fw) & Total sugar $(\mathrm{g} / 100 \mathrm{~g}$ fw) \\
\hline Control & $241.79 \pm 0.17$ & $198.09 \pm 0.09$ & $22.49 \pm 0.17$ & $46.98 \pm 0.58$ & $4.49 \pm 0.06$ \\
Treated & $246.47 \pm 0.61$ & $204.16 \pm 0.02$ & $23.60 \pm 0.25$ & $46.60 \pm 0.26$ & $5.50 \pm 0.06$ \\
\hline
\end{tabular}

TPC total phenolic content (Folin-Ciocalteu assay)

Total sugar: sum of fructose, glucose and sucrose

Total anthocyanins: sum of pelargonidin-3-glucoside (Pg3G), cyanidin-3-glucoside (Cy3G) and pelargonidin-3-rutinoside (Pg3R).Data are mean \pm SD $(n=3)$. Treated samples: $1000-\mu \mathrm{M}$ CUR and 10-min exposure to light (light dosage $\left.42 \mathrm{~J} / \mathrm{cm}^{2}\right) . p>0.05$ compared to the control group without CUR and light treatment 


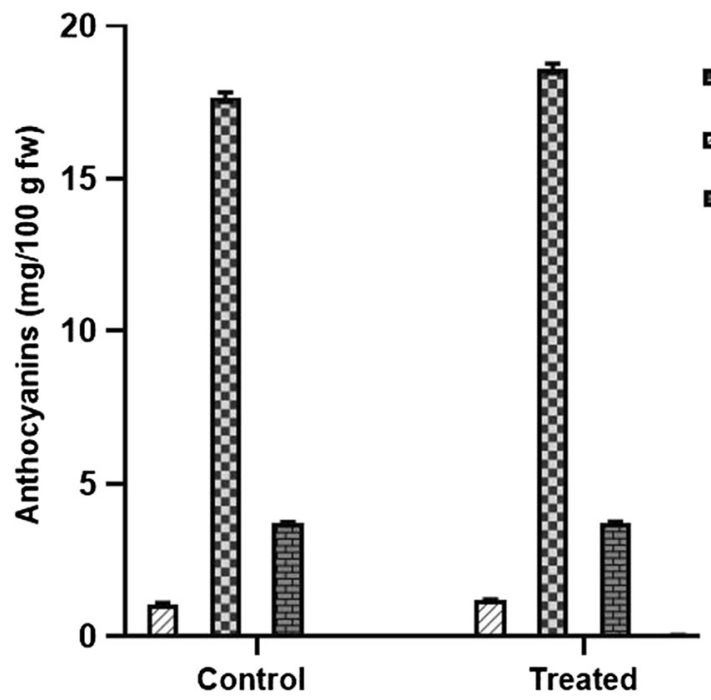

Fig. 3 Effect of photosensitization on individual anthocyanins in Albion strawberries. Treated samples: $1000 \mu \mathrm{M}$ CUR and $10 \mathrm{~min}$ exposure to light (light dosage $42 \mathrm{~J} / \mathrm{cm}^{2}$ ). $p>0.05$ compared to the control group without CUR and light treatment. Data are mean $\pm \operatorname{SD}(n=3)$

$100 \mathrm{~g}$ fw (Fredericks et al. 2013). Photosensitization had no impact on ascorbic acid (46.98 vs. $46.60 \mathrm{mg} / 100 \mathrm{~g} \mathrm{fw}$ ) (Table 2). A previous study by Rasiukevičiūtè et al. (2016) found that photosensitization mediated by chlorophyllin derivative did not alter the ascorbic acid content. This is a clear indication that photosensitization has no impact on ascorbic acid, an important natural antioxidant and vitamin in strawberry.

\section{Sugar Content}

Total sugar content in photosensitized strawberry fruit increased by $22 \%$ compared to the control (Table 2). The increase in fructose, glucose and sucrose in photosensitized strawberry fruit was $31 \%, 22 \%$ and $11 \%$, respectively, compared to the untreated control fruit (Fig. 4). The results are supported by refractometer analysis of TSS which showed a $9 \%$ increase $(p<0.05)$ in photosensitized fruits compared to the control (Table 1). Aurum and Nguyen (2019) reported an increase in TSS in grapes treated with curcumin-based photosensitization at a light dose of $36.3 \mathrm{~J} / \mathrm{cm}^{2}$ up to 4 days of storage at $37^{\circ} \mathrm{C}$. This increase could be caused by dehydration (Valverde et al. 2005) and activity of hydrolytic enzymes (Nabifarkhani et al. 2015). Moreover, Baka et al. (1999) found that strawberries treated with UV-C (doses 0.25 and $1.0 \mathrm{~kJ} / \mathrm{m}^{2}$ ) and stored at $4{ }^{\circ} \mathrm{C}$ increased free sugar content up to 6 days. This accumulation of sugars could be related to UV stress and the stimulation of intercellular synthetic enzymes, such as the activity of sucrose synthase, and inhibition of degradative enzymes, such as invertase or phosphorylase (Stitt and Steup 1985). In our study, increase amount of sugar level could be attributed to stimulation

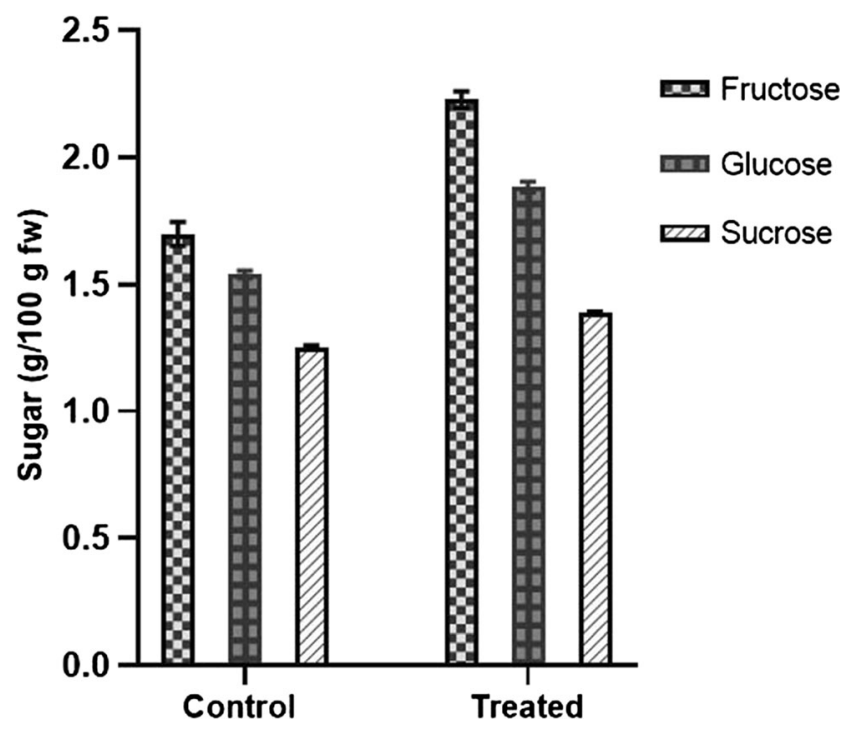

Fig. 4 Effect of photosensitization on individual sugars in Albion strawberries. Treated samples: $1000 \mu \mathrm{M}$ CUR and $10 \mathrm{~min}$ exposure to blue xenon light (light dosage $42 \mathrm{~J} / \mathrm{cm}^{2}$ ). $p>0.05$ compared to the control group without CUR and light treatment. Data are mean $\pm \mathrm{SD}(n=3)$

of intercellular synthetic enzymes due to effect of photosensitizer (CUR) and/or visible light (420 nm). However, further investigations will be required to understand the physiological basis of increased sugar content of strawberry fruits after photosensitization.

\section{Conclusion}

Fresh strawberry fruit when photosensitized by the combination of visible blue light and $1000 \mu \mathrm{M}$ CUR and stored at $4 \pm$ $2{ }^{\circ} \mathrm{C}$ extended the shelf life up to 12 days compared to 8 days in the untreated control fruits. Photosensitization did not affect the physicochemical quality of the strawberry and retained key quality attributes. It is worth emphasizing that there was an increase in total soluble solids and sugar content of photosensitized strawberries which can increase consumer acceptance. These results suggest that photosensitization may be a useful non-thermal treatment technology for maintaining strawberry fruit quality and extending shelf life. However, further detailed studies on the impact of photosensitization on other macro- and micronutrients, bioactive compounds as well as sensory attributes are warranted to evaluate the effectiveness of photosensitization on quality of strawberry fruit.

Funding Shammy Sarwar acknowledges the support from the Australian Government for the Research Training Program Scholarship for her $\mathrm{PhD}$ study at the University of Queensland, Australia. Funding support from Horticulture Innovation Australia Limited through the HN15001 Naturally Nutritious project and technical assistance from the Queensland Department of Agriculture and Fisheries are also acknowledged. 


\section{Compliance with Ethical Standards}

Conflict of Interest The authors declare that they have no conflict of interest.

\section{References}

Agati G, Tattini M (2010) Multiple functional roles of flavonoids in photoprotection. New Phytol 186(4):786-793. https://doi.org/10. 1111/j.1469-8137.2010.03269.x

Al-Asmari F, Mereddy R, Sultanbawa Y (2017) A novel photosensitization treatment for the inactivation of fungal spores and cells mediated by curcumin. J Photochem Photobiol B 173:301-306. https:// doi.org/10.1016/j.jphotobiol.2017.06.009

Al-Asmari F, Mereddy R, Sultanbawa Y (2018) The effect of photosensitization mediated by curcumin on storage life of fresh date (Phoenix dactylifera L.) fruit. Food Control 93:305-309. https:// doi.org/10.1016/j.foodcont.2018.06.005

Aurum FS, Nguyen LT (2019) Efficacy of photoactivated curcumin to decontaminate food surfaces under blue light emitting diode. J Food Process Eng 42(3):e12988. https://doi.org/10.1111/jfpe.12988

Baka M, Mercier J, Corcuff R, Castaigne F, Arul J (1999) Photochemical treatment to improve storability of fresh strawberries. J Food Sci 64(6):1068-1072. https://doi.org/10.1111/j.1365-2621.1999. tb12284.x

Brovko, Anany H, Bayoumi M, Giang K, Kunkel E, Lim E et al (2014) Antimicrobial light-activated materials: towards application for food and environmental safety. J Appl Microbiol 117(5):1260-1266. https://doi.org/10.1111/jam.12622

Chen B, Huang J, Li H, Zeng Q-H, Wang JJ, Liu H, Pan Y, Zhao Y (2020) Eradication of planktonic Vibrio parahaemolyticus and its sessile biofilm by curcumin-mediated photodynamic inactivation. Food Control:113. https://doi.org/10.1016/j.foodcont.2020.107181

Cheng X-F, Zhang M, Adhikari B (2014) Changes in quality attributes of strawberry purees processed by power ultrasound or thermal treatments. Food Sci Technol Res 20(5):1033-1041. https://doi.org/10. 3136/fstr.20.1033

Chiabrando V, Giuggioli N, Maghenzani M, Peano C, Giacalone G (2018) Improving storability of strawberries with gaseous chlorine dioxide in perforated clamshell packaging. Pol J Food Nutr Sci 68(2):141-148. https://doi.org/10.1515/pjfns-2017-0024

Fredericks CH, Fanning KJ, Gidley MJ, Netzel G, Zabaras D, Herrington M, Netzel M (2013) High-anthocyanin strawberries through cultivar selection. J Sci Food Agric 93(4):846-852. https://doi.org/10.1002/ jsfa.5806

Gasperotti M, Masuero D, Mattivi F, Vrhovsek U (2015) Overall dietary polyphenol intake in a bowl of strawberries: the influence of Fragaria spp. in nutritional studies. J Funct Foods 18:1057-1069. https://doi.org/10.1016/j.jff.2014.08.013

Jiang Y, Leung AW, Wang X, Zhang H, Xu C (2013) Inactivation of Staphylococcus aureus by photodynamic action of hypocrellin B. Photodiagn Photodyn Ther 10(4):600-606. https://doi.org/10.1016/ j.pdpdt.2013.06.004

Lemoine ML, Chaves AR, Martínez GA (2010) Influence of combined hot air and UV-C treatment on the antioxidant system of minimally processed broccoli (Brassica oleracea L. var. Italica). LWT Food Sci Technol 43(9):1313-1319. https://doi.org/10.1016/j.lwt.2010.05. 011

Lin Y, Hu J, Li S, Hamzah SS, Jiang H, Zhou A, Zeng S, Lin S (2019) Curcumin-based photodynamic sterilization for preservation of fresh-cut Hami melon. Molecules 24(13). https://doi.org/10.3390/ molecules 24132374
Liu, Li Z, Cao B, Wu J, Wang Y, Xue Y et al (2016) The effect of a novel photodynamic activation method mediated by curcumin on oyster shelf life and quality. Food Res Int 87:204-210. https://doi.org/10. 1016/j.foodres.2016.07.012

Liu, Zheng H, Sheng K, Liu W, Zheng L (2018) Effects of melatonin treatment on the postharvest quality of strawberry fruit. Postharvest Biol Technol 139:47-55. https://doi.org/10.1016/j.postharvbio. 2018.01.016

Luksiene Z, Paskeviciute E (2011) Novel approach to the microbial decontamination of strawberries: chlorophyllin-based photosensitization. J Appl Microbiol 110(5):1274-1283. https://doi.org/10.1111/j. 1365-2672.2011.04986.x

Maraei RW, Elsawy KM (2017) Chemical quality and nutrient composition of strawberry fruits treated by $\gamma$-irradiation. J Radiat Res Appl Sci 10(1):80-87. https://doi.org/10.1016/j.jrras.2016.12.004

Matar C, Gaucel S, Gontard N, Guilbert S, Guillard V (2018) Predicting shelf life gain of fresh strawberries ' Charlotte cv' in modified atmosphere packaging. Postharvest Biol Technol 142:28-38. https:// doi.org/10.1016/j.postharvbio.2018.03.002

Musa KH, Abdullah A, Kuswandi B, Hidayat MA (2013) A novel high throughput method based on the DPPH dry reagent array for determination of antioxidant activity. Food Chem 141(4):4102-4106. https://doi.org/10.1016/j.foodchem.2013.06.112

Nabifarkhani N, Sharifani M, Daraei Garmakhany A, Ganji Moghadam E, Shakeri A (2015) Effect of nano-composite and Thyme oil (Tymus Vulgaris L) coating on fruit quality of sweet cherry (Takdaneh Cv) during storage period. Food Sci Nutr 3(4):349354. https://doi.org/10.1002/fsn3.226

Nadim Z, Ahmadi E, Sarikhani H, Amiri Chayjan R (2015) Effect of methylcellulose-based edible coating on strawberry Fruit's quality maintenance during storage. J Food Process Preserv 39(1):80-90. https://doi.org/10.1111/jfpp.12227

Neri F, Cappellin L, Spadoni A, Cameldi I, Algarra Alarcon A, Aprea E, Romano A, Gasperi F, Biasioli F (2015) Role of strawberry volatile organic compounds in the development of Botrytis cinerea infection. Plant Pathol 64(3):709-717. https://doi.org/10.1111/ppa.12287

Netzel M, Fanning K, Netzel G, Zabaras D, Karagianis G, Treloar T et al (2012) Urinary excretion of antioxidants in healthy humans following queen garnet plum juice ingestion: a new plum variety rich in antioxidant compounds. J Food Biochem 36(2):159-170. https:// doi.org/10.1111/j.1745-4514.2010.00522.x

Nunes MCN, Brecht JK, Morais AMMB, Sargent SA (1995) Physical and chemical quality characteristics of strawberries after storage are reduced by a short delay to cooling. Postharvest Biol Technol 6(1): 17-28. https://doi.org/10.1016/0925-5214(94)00048-W

Paskeviciute, Zudyte B, Luksiene Z (2018) Towards better microbial safety of fresh produce: Chlorophyllin-based photosensitization for microbial control of foodborne pathogens on cherry tomatoes. J Photochem Photobiol B 182:130-136. https://doi.org/10.1016/j. jphotobiol.2018.04.009

Penha CB, Bonin E, da Silva AF, Hioka N, Zanqueta ÉB, Nakamura TU, de Abreu Filho BA, Campanerut-Sá PAZ, Mikcha JMG (2017) Photodynamic inactivation of foodborne and food spoilage bacteria by curcumin. LWT Food Sci Technol 76:198-202. https://doi.org/ 10.1016/j.lwt.2016.07.037

Phan ADT, Chaliha M, Sultanbawa Y, Netzel ME (2019) Nutritional characteristics and antimicrobial activity of Australian grown Feijoa (Acca sellowiana). Foods 8(9). https://doi.org/10.3390/ foods 8090376

Priyadarsini KI (2014) The chemistry of curcumin: from extraction to therapeutic agent. Molecules 19(12):20091-20112. https://doi.org/ 10.3390/molecules191220091

Rasiukevičiūte N, Valiuškaite A, Uselis N, Buskienè L, Viškelis J, Lukšiene Ž (2015) New non-chemical postharvest technologies reducing berry contamination. Zemdirbyste-Agric 102(4):411-416. https://doi.org/10.13080/z-a.2015.102.052 
Rasiukevičiūtè N, Valiuškaitė A, Uselis N, Viškelis J, Luksiene Z (2016) Attempts to use photosensitization for preservation of strawberry cultivar 'Darselect': effects on shelf-life, nutritional and organoleptic properties excluding photosensitization for preservation of strawberry. J Plant Dis Prot 123(3):125-131. https://doi.org/10.1007/ s41348-016-0020-5

Sikora M, Swieca M (2018) Effect of ascorbic acid postharvest treatment on enzymatic browning, phenolics and antioxidant capacity of stored mung bean sprouts. Food Chem 239:1160-1166. https:// doi.org/10.1016/j.foodchem.2017.07.067

Stitt M, Steup M (1985) Starch and sucrose degradation. In: Douce R, Day DA (eds) Higher plant cell respiration. Encyclopedia of plant physiology (new series), vol 18. Springer, Berlin. https://doi.org/10. 1007/978-3-642-70101-6_13

Strazzi Sahyon HB, Silva PPD, Oliveira MS, Cintra LTA, Dezan-Junior E, Gomes-Filho JE et al (2019) Influence of curcumin photosensitizer in photodynamic therapy on the mechanical properties and push-out bond strength of glass-fiber posts to intraradicular dentin. Photodiagn Photodyn Ther 25:376-381. https://doi.org/10.1016/j. pdpdt.2019.01.025

Tao R, Zhang F, Tang QJ, Xu CS, Ni ZJ, Meng XH (2019) Effects of curcumin-based photodynamic treatment on the storage quality of fresh-cut apples. Food Chem 274:415-421. https://doi.org/10.1016/ j.foodchem.2018.08.042
Temba BA, Fletcher MT, Fox GP, Harvey J, Okoth SA, Sultanbawa Y (2019) Curcumin-based photosensitization inactivates Aspergillus flavus and reduces aflatoxin B1 in maize kernels. Food Microbiol 82:82-88. https://doi.org/10.1016/j.fm.2018.12.013

Valverde JM, Guillén F, Martínez-Romero D, Castillo S, Serrano M, Valero D (2005) Improvement of table grapes quality and safety by the combination of modified atmosphere packaging (MAP) and eugenol, menthol, or thymol. J Agric Food Chem 53(19):7458 7464. https://doi.org/10.1021/jf050913i

Wang CY, Chen C-T, Wang SY (2009) Changes of flavonoid content and antioxidant capacity in blueberries after illumination with UV-C. Food Chem 117(3):426-431. https://doi.org/10.1016/j.foodchem. 2009.04.037

Xu F, Shi L, Chen W, Cao S, Su X, Yang Z (2014) Effect of blue light treatment on fruit quality, antioxidant enzymes and radicalscavenging activity in strawberry fruit. Sci Hortic 175:181-186. https://doi.org/10.1016/j.scienta.2014.06.012

Yan J, Luo Z, Ban Z, Lu H, Li D, Yang D, Aghdam MS, Li L (2019) The effect of the layer-by-layer (LBL) edible coating on strawberry quality and metabolites during storage. Postharvest Biol Technol 147: 29-38. https://doi.org/10.1016/j.postharvbio.2018.09.002

Publisher's Note Springer Nature remains neutral with regard to jurisdictional claims in published maps and institutional affiliations. 